\section{Creutzfeldt-Jakob disease and bovine spongiform encephalopathy}

Magnetic resonance imaging may have a role in diagnosing Creutzfeldt-Jakob disease

EdrToR,-Creutzfeldt-Jakob disease' is still rarely diagnosed in Britain, and neuropathological examination is required to confirm the diagnosis. Research in the United States, however, has shown the presence of bilaterally symmetric hyperintense abnormalities in the basal ganglia in T2 weighted magnetic resonance images in patients with pathologically proved Creutzfeldt-Jakob disease. ${ }^{2}$ This abnormality on magnetic resonance imaging was first reported in $1988 .{ }^{3} \mathrm{~A}$ colleague and I have reported Creutzfeldt-Jakob disease, with signal abnormalities in the basal ganglia on magnetic resonance imaging, in a 58 year old man with no occupational exposure to animals who presented with progressive dementia. ${ }^{4}$

The prevalence of hyperintense abnormalities in the basal ganglia in T2 weighted images in patients with Creutzfeldt-Jakob disease has not been studied and remains unknown. Such hyperintense abnormalities in the basal ganglia can be seen in several disorders, but a combination of clinical features, laboratory findings, and imaging characteristics can be used to distinguish the other conditions from Creutzfeldt-Jakob disease. Although the absence of bilateral symmetric hyperintense lesions in the basal ganglia does not exclude Creutzfeldt-Jakob disease, it is reasonable to assume that their presence in patients with rapidly progressive dementia is a specific sign of the disease. It would be useful to know of other documented cases in which magnetic resonance imaging was carried out before death. Surely it would be worth while pursuing further research in this field and collating data from several centres with an interest in Creutzfeldt-Jakob disease to evaluate the role of magnetic resonance imaging in this condition.

TERENCE FEATHERSTON Consultant radiologis

Department of Radiology, Darlington Memorial Hospital,

Darlington DL3 6HX

1 Almond JW, Brown P, Gore SM, Hofman A, Wientiens DPWM Ridley RM, et al. Will bovine spongiform encephalopathy transmit to humans? $B M F$ 1995;311:1415-21. (25 November.)

2 Barboriak DP, Provenzale JM, Boyko OB. MR diagnosis of Creutzfeldt-Jakob disease: significance of high signal intensity of the basal ganglia. $A \not R R$ 1994;162:137-40.

3 Gertz HJ, Henkes H, Cervos-Navarro J. Creutzfeldt-Jakob disease: correlation of MRI and neuropathologic findings. Neurology 1988;38:1481-2

4 Featherstone $T$, Weerasinghe $S$. Creutzfeldt-Jakob disease-can MRI help in diagnosis? International fournal of Geriatric Psychiatry (in press).

\section{Aetiology of scrapie in certain circumstances is not evidence against another aetiology in different circumstances}

EdToR,-We are pleased that, in the commentary on our article on the myth of maternal transmission of spongiform encephalopathy, R G Will agrees that maternal transmission does not occur in human or experimental forms of spongiform encephalopathy and that the only circumstance in

\section{Advice to authors}

We receive more letters than we can publish: we can currently accept only about one third. We prefer short letters that relate to articles published within the past four weeks. Letters received after this deadline stand less chance of acceptance. We also publish some "out of the blue" letters, which usually relate to matters of public policy.

When deciding which letters to publish we favour originality, assertions supported by data or by citation, and a clear prose style. Wit, passion, and personal experience also have their place.

Letters should have fewer than 400 words and no more than five references (including one to the $\mathrm{BMJ}$ article to which they relate); references should be in the Vancouver style. We welcome pictures.

Letters should be typed and signed by each author, and each author's current appointment and address should be stated. We encourage you to declare any conflict of interest.

Please enclose a stamped addressed envelope if you would like to know whether your letter has been accepted or rejected.

Letters will be edited and may be shortened.

which it requires serious consideration is natural scrapie.'

The genetics of natural scrapie and the genetics of susceptibility to experimental transmission of scrapie in sheep differ. The characteristics and quantity of the agent, the route of exposure, and the interaction between the host genotype and the strain of agent are known only for, or are relevant only to, experimental transmission; in some cases they apply only to the laboratory disease in rodents. Data on experimental transmission are therefore of only limited relevance to natural scrapie.

The occurrence of scrapie in two of 20 Suffolk sheep exported from New Zealand in the 1960s is interesting, but, obviously, if New Zealand were free of scrapie at that time then these two animals could not have acquired scrapie by maternal transmission or other perinatal events. Care should be taken, however, in interpreting these data, since the scrapie free status of New Zealand applies to the 70 million strong national sheep flock, which is based largely on English Romneys, Lincolns, Southdowns, and sub-breeds of Merinos. ${ }^{2}$ Natural scrapie has rarely if ever been recorded in these breeds. ${ }^{3}$ The number of Suffolks in New Zealand is extremely small, and all the cases of scrapie in New Zealand have occurred in Suffolks. ${ }^{4}$ Similarly, almost all the outbreaks of scrapie in Canada, the United States, and Australia have been in Suffolks. ${ }^{5}$

The point of our article is that there is no evidence for maternal transmission of any form of spongiform encephalopathy and that the epidemiology of natural scrapie is adequately explained by the sheep genotype. Spongiform encephalopathy is undoubtedly transmissible, and knowledge of the circumstances in which transmission occurs is extremely important both for the control of the disease in animals and for the prevention of disease in humans, especially since, in the West, all known acquired cases in humans have been iatrogenic.
But a better understanding of the disease process is achieved when it is recognised that cases are either idiopathic or acquired and that evidence for one aetiology in certain circumstances is not evidence against another aetiology in different circumstances.

R M RIDLEY gnition team H F BAKER Senior scientific officer

Department of Experimental Psychology, Cambridge University, Cambridge CB2 3EB

1 Ridley RM, Baker HF. The myth of maternal transmission of spongiform encephalopathy. BMf 1995;311:1071-6. [With commentary by $\mathrm{R} G$ Will.] (21 October.)

2 Bruere AN. Scrapie: a point of view. New Zealand Veterinar fournal 1977;25:259-60.

3 Parry HB. Scrapie disease in sheep; historical, clinical, epidemiological and practical aspects of the natural disease. London Academic Press, 1983.

4 Brash AG. Scrapie in imported sheep in New Zealand. New Zealand Veterinary fournal 1952;1:27-30.

5 Hourrigan JL, Klingsporn A, Clark WW, de Camp M. Epidemiology of scrapie in the United States. In: Prusiner SB, demiology WI scrapis in the Unird system. Vol. 1. New York: Academic Press, 1979:331-56.

\section{Bovine spongiform encephalopathy is being maintained by vertical and horizontal transmission}

EDITOR,-In their article looking at the possibility of maternal transmission of spongiform encephalopathy R M Ridley and H F Baker analyse previously published information and conclude that natural sheep scrapie has a genetic basis. ${ }^{1}$ Of course this is so. Because of the absence of nucleic acid within the infective particle, host genome is required for the pathogenesis of the disease, ${ }^{2}$ and it follows that such genes are inherited in various ways. This in no way negates the well established observations that the transmissible spongiform encephalopathies are due to infectious agents which are acquired by vulnerable hosts in a variety of ways, including maternal transmission. ${ }^{3}$ Maternal transmission cannot sustain the disease in a species in the long term, but it will occur in association with horizontal transmission due, for example, to several lambs or ewes eating or having contact with an infected placenta. ${ }^{4}$

Ridley and Baker omit to provide any of the evidence supporting the occurrence of vertical and horizontal transmission of the infectious agent for bovine spongiform encephalopathy under farm conditions. This evidence includes the following.

By early 1989 bovine spongiform encephalopathy had been carefully studied for three years, and it was predicted that the total number of cases would be $17000-20000$, on the assumption that neither vertical nor horizontal transmission occurred. ${ }^{5}$ By 26 October 1995 the number of cases of bovine spongiform encephalopathy that had been confirmed in the United Kingdom was $154150 .^{6}$

Because of the belief that recycled animal remains was the cause of bovine spongiform encephalopathy ${ }^{5}$ this practice was made illegal from 18 July 1988 after extensive consultation. Indeed, in early 1989 this ban was considered to have been implemented effectively. ${ }^{5}$ From September 1988 to April 1989, newborn calves were removed from 600 dams by the Ministry of Agriculture, Fisheries and Food and were reared on fresh grass so that the extent, if any, of vertical transfer could be quantified.' By January 1995 more than 30 of 
these animals had died of bovine spongiform encephalopathy, ${ }^{7}$ although the details of the experiment have not been published.

Furthermore, since the ban on cannibalistic feeding was imposed in 1988 over 22000 animals have been born that have subsequently developed bovine spongiform encephalopathy; one was born as recently as June 1993. Interestingly, the range of ages at which the disease was diagnosed in these animals is virtually the same as that in animals born before the ban (table).

Distribution of ages of animals with confirmed bovine spongiform encephalopathy born before and after feed containing recycled animal remains was banned in July 1988. Figures are numbers (percentages)

\begin{tabular}{lrr}
\hline $\begin{array}{l}\text { Age } \\
\text { (years) }\end{array}$ & $\begin{array}{c}\text { Born before ban, } \\
\text { disease diagnosed } \\
\mathbf{1 9 8 9 ^ { 3 * }}\end{array}$ & $\begin{array}{c}\text { Born after ban, } \\
\text { disease diagnosed } \\
\mathbf{1 9 9 0 - 5 t}\end{array}$ \\
\hline $1-$ & $1(0.02)$ & $1(0.004)$ \\
$2-$ & $28(0.52)$ & $81(0.36)$ \\
$3-$ & $586(10.81)$ & $2824(12.44)$ \\
$4-$ & $2138(39.45)$ & $9820(43.24)$ \\
$5-$ & $1874(34.58)$ & $7966(35.08)$ \\
$6-$ & $667(12.30)$ & $2008(8.84)$ \\
$7-8$ & $125(2.31)$ & $9(0.04)$ \\
\hline
\end{tabular}

*England and Wales.

tData given in letter from A Browning (minister for food Ministry of Agriculture, Fisheries and Food) to D Hinchcliffe (member of parliament), Nov 1995.

These figures show that bovine spongiform encephalopathy is now endemic and is being maintained by vertical and horizontal transmission. However, the Ministry of Agriculture, Fisheries and Food maintains that all the affected animals that were born after the ban were exposed to remnants of contaminated feed (data given in letter from A Browning (minister for food) to D Hinchcliffe (member of parliament), Nov 1995), ${ }^{67}$ with the implication that those involved in the production of feed and also farmers have been breaking the law on a massive scale. But if traces of infectivity from the feed were responsible for the disease in these animals, the animals would be expected to be older, as the incubation period of transmissible spongiform encephalopathies is inversely related to the infecting dose. ${ }^{3}$

R W I ACEY

Department of Microbiology,

Professor of clinical microbiolog

University of Leeds,

Chapel Allerton Hospital,

Leeds LS7 4SA

1 Ridley RM, Baker HF. The myth of maternal transmission of spongiform encephalopathy. $B M 7$ 1995;311:1071-6. With spongiform encephalopathy. $B M \mathcal{F} 1995$

2 Beuler H, Aguzzi A, Sailor A, Greiner RA, Autenried P, Aget M, et al. Mice devoid of PrP are resistant to scrapie. Cell 1993;73:1339-47.

3 Dealler SF, Lacey RW. Transmissible spongiform encephalopathies: the threat of BSE to man. Food Microbiology 1990;7: 253-79.

4 Dickinson AG, Young GB, Stamp JT, Renwick CC. An analysis of natural scrapie in Suffolk sheep. Heredity 1965;20:485-503.

5 Southwood R. Report of the working party on bovine spongiform encephalopathy. London: HMSO, 1989.

6 Hinchliffe D, parliamentary question to Browning A. House of Commons official report (Hansard) 1995 Oct 31;265:cols 219-23. (No 154.)

7 Hinchliffe D, parliamentary question to Browning A. House of Commons official report (Hansard) 1995 Jan 31;253:cols 645-7. (No 42.)

\section{Scrapie can be transmitted to mice by instillation of inoculum into the conjunctiva}

EDITOR,-None of the articles discussing the possible routes of transmission of spongiform encephalopathies cite a particular piece of evidence. ${ }^{1}$ In 1993 the three of us showed that scrapie can be successfully transmitted to mice merely by instillation of inoculum into the conjunctiva. ${ }^{2}$ Around a quarter of mice infected with either the
ME7 or the 79A strain of scrapie developed the disease. The incidence and incubation period for the mice infected with the ME7 strain were similar to those shown for oral infection, although the lesion profile (the pattern and intensity of the vacuolar pathology in the brain) was higher for the group infected orally. We pointed out that, apart from oral infection, this is the only recognised non-invasive route of infection for these diseases, and we concluded that "these results demonstrate the necessity for adequate eye protection when handling tissues infected with spongiform encephalopathies."

In view of the current concern over CreutzfeldtJakob disease and bovine spongiform encephalopathy, this work should not be overlooked.

$\begin{array}{rr}\text { JANET R FRASER } & \text { JAMES D FOSTER } \\ \text { Senior research scientist } & \text { Research scientist } \\ & \text { HUGH FRASER } \\ & \text { Consultant neuropathologist }\end{array}$

Institute for Animal Health, Consultant neuropathologist

Biological and Biotechnological Scientific Research Council/ MRC Neuropathogenesis Unit, Edinburgh EH9 3JF

1 Almond JW, Brown P, Gore SM, Hofman A, Wientsjens DPWM, Ridley RM, et al. Creutzfeldt-Jakob disease and bovine spongiform encephalopathy: any connection? $B M F$ 1995;311:1415-21. (25 November.)

2 Scott JR, Foster JD, Fraser H. Conjunctival instillation of scrapie in mice can produce disease. Vet Microbiol 1993;34: 305-9.

\section{Meat and Livestock Commission's advertising campaign}

\section{Commission defends campaign}

EDITOR,-Gill Langley's review of the Meat and Livestock Commission's advertising campaign "Meat matters" suggests either that the author has only superficial nutritional knowledge or that her interpretation of our campaign is clouded by her apparent bias towards vegetarianism.' She suggests that an acceptable alternative to steak that would provide similar amounts of absorbable iron might be cooked soya beans, cauliflower, and baked potato with coleslaw. Is such a bland combination really supposed to compare with a steak meal, which would still provide more absorbable iron since meat not only contains haem iron but also enhances absorption of non-haem iron in the vegetables and cereals it accompanies?

Langley correctly points out that spinach is not the best plant source of iron. Yet market research among consumers and health professionals has shown that spinach is the icon when it comes to iron. With increasing concerns about iron deficiency in Britain, it is appropriate that we tel the public how valuable red meat is as a source of iron; hence the comparison with spinach.

The review misses the true significance of the commission's campaign. It is precisely because the fat content in red meat has fallen that such a campaign is possible and timely. Too many people have cut back on red meat in the mistaken belief that to do so will improve their diet. If only it were so simple.

The Committee on Medical Aspects of Food Policy has recommended that fat intake should be reduced to $33-35 \%$ of energy intake, ${ }^{2}$ but this recommendation applies to our whole diet averaged over several days, not to individual foods. To apply this recommendation in this incorrect way would result in many healthier foods being blacklisted, including oily fish, olive oil, and low fat spread.

Finally, Langley's comment about the Meat and Livestock Commission making "sideswipes" at vegetarians is unjustified. The commission is simply alerting health professionals and consumers to new nutritional facts about the fat content of meat, as well as to the dangers of consuming too little iron. As eating patterns change and the traditional "meat and two veg" meal becomes less common it is important that everyone takes steps to eat a balanced diet, whether this includes a high or low proportion of meat or none at all. The Committee on Medical Aspects of Food Policy makes clear that those who avoid eating meat should think carefully about replacing the nutrients that meat provides.

CHRIS LAMB

Consumer marketing manager

PO Box 44,

Milton Keynes MK6 IAX

1 Langley G. Legal, decent, honest, and truthful. $B M \mathcal{F}$ 1995;311 1442. (25 November.)

2 Department of Health. Dietary reference for food energy and nutrients for the United Kingdom: report of the panel on dietary reference values, Committee on Medical Aspects of Food Policy. London: HMSO, 1991. (Report in health and social subjects No 41.)

**A complaint about one of the commission's advertisements has recently been upheld by the Advertising Standards Authority (see News) EDITOR

\section{Author may not be impartial}

EDrTOR,-At the end of Gill Langley's critical piece about the Meat and Livestock Commission's recent advertising campaign, Langley is stated to be a scientific consultant and freelance writer.' Readers may not be aware that Langley's regular employment for the past five or so years has been as scientific adviser to the Dr Hadwen Trust and to Animal Aid, two uncompromising animal rights organisations. She also describes herself as "an animal rightist and a vegan since 1978." In the piece she criticises the Meat and Livestock Commission for not running an impartial educational exercise. Given her partisan position, the same criticism could be made of her review article.

My own organisation, which resists the pressure of the antivivisection movement, holds no brief for any organisation that promotes the use of meat as food.

SIMON BROPHY

Biomedical Research Education Trust, Director

London W1R 8QD

1 Langley G. Legal, decent, honest, and truthful. BMF 1995;311: 1442. (25 November.)

\section{Commission emphasises nutritional value of meat in booklet for new mothers}

EDITOR,-As well as conducting a general advertising campaign ${ }^{1}$ the Meat and Livestock Commission seems to be targeting a particularly vulnerable group: new mothers. When I made a routine visit to the local health centre with my 3 month old daughter the health visitor gave me a booklet about weaning, which stated that it had been produced with the support of the Health Visitors Association. ${ }^{2}$ The booklet contained some useful information but with an emphasis on meat as a source of iron and other nutrients. It was when I got to the recipes, each one containing "British" red meat, that I turned to the back to find that the booklet had been published by the Meat and Livestock Commission. The Health Education Authority's book New Birth to Five, which mothers are given free, contains a section on weaning. ${ }^{3}$ Surely it would be better to remind mothers of this than to distribute disguised advertisements.

JUITH R GLYNN Lecturer in epidemiology

London School of Hygiene and Tropical Medicine London WC1E 7HT

1 Langley G. Legal, decent, honest, and truthful. BMf 1995;311: 1442. (25 November)

2 Robert-Sargeant S. Weaning with family meals. Getting it right. Milton Keynes: Meat and Livestock Commission, 1995.

3 Kohner N, Phillips A, Ford K. New birth to five. A complete guide to the first five years of being a parent. London: Health Education Authority, 1994. 